\title{
AN URBAN HOME AND SCHOOL LEAGUE
}

\author{
By Walter L. Philips, A.M., \\ Supervising Principal of Public Schools, Lansdowne, Pennsylvania.
}

The home and school league is an organization of those persons interested in the education of the children, and in a larger sense of the community. Although their history is brief, they have already become a mighty force in bringing about the right kind of progress in a community. They supply the means whereby the community may express itself concerning its life and activities and they are a powerful coöperating force in making effective ideas that stand for progress. The demands for a practical education have caused remarkable changes in school curricula, especially those of the secondary and higher schools. The home and school league aids parents, teachers, and school officials in keeping informed of the changes occurring. The politician, the grafter, and the unfit are no longer tolerated in modern school circles. The home and school league has become an effective agent in the elimination of such persons from control. In the districts in which these associations are frowned upon or prohibited, a free expression of public opinion is unwelcome. When managed aright they coöperate with the legally chosen school officials when school affairs are managed with care and discretion.

\section{Advertising and Creating Interest}

As an incentive to the formation of a home and school league interest in the schools must be created. The school must be kept before the people. Its needs, aims and policy must be advertised in a legitimate manner in order to secure the coöperation a home and school league can give. Exhibitions of school work, musicales, art displays and contests never fail to arouse interest. The interest of the community having been secured, the desire for a home and school league should originate with the school administration who, it is presumed, welcomes the coöperation of the parents. When parents and friends realize that the school is merely a factor cooperating with the home, there is little or no difficulty in forming 
an organization for mutual support. Interest in educational matters should be interpreted by the governing committee of the league, and this can rightly form a basis for the work of the organization.

\section{Number and Character of Meetings}

The number of meetings for the school year depends upon the needs of the community. Two meetings before December 25 and three after that date seem to meet the needs of the league of this district. Regular meetings are not planned for the mere entertainment of members. As indicated in the foregoing statements meetings are planned for the discussion of some community problem, for the presentation to teachers and parents of some problem which will better help them in the training of the children of the district. It is a form of university extension brought into the school house. Questions bearing upon the moral training of children; on activities for the extra-school hours; the needs of the school district, etc., are discussed. A brief list of subjects follows: The Problem of Home Preparation of School Work; The Moral Training of Children; The Self Realization of Pupils and Parents; The Need of a Playground; Better School Facilities; Vocational Guidance; Some Higher Thoughts for Teachers and Parents; The Reading Matter of Children; The Health of the Child; Eye Strain; The Meaning of a Flower (Parenthood). Among the most profitable meetings are those in which the discussion of problems is carried on by the teachers and parents themselves. There is an exchange of ideas, a presentation of the two points of view in the education of the child, and a mutual understanding of the best methods to adopt in this training.

It is well occasionally to invite those not connected with the schools to address meetings of parents and teachers, giving them the advantage of their more complete study and experience, along their special lines of work. The breadth of the educational processes can often be made more evident by such formal addresses. Local problems, however, can usually be solved best by the people most directly affected, provided that there are men and women with sufficient wisdom to direct the discussion toward the right end. The purely entertainment features should not be omitted entirely. These, however, are of secondary importance and should not divert the time and interest from consideration of the more vital problems 
to be brought before parents and teachers. In this district, one meeting a year is given to the inspection of children's work. Specimens of the work of all grade school children and almost all high school students are put into convenient places so that parents may inspect the work and compare that of their own children with the work of others.

Conferences of fathers and of mothers are frequently held an hour previous to the general meetings. Questions concerning the different sexes are discussed freely. Sentiment is created relative to what is best for boys and for girls in education. One result of these discussions is the further development of the physical education department of the public schools to the extent of procuring a well trained woman of much experience for physical training work for girls and a well trained man with successful experience for physical training work for boys.

\section{Community Spirit Developed}

The social features of the meetings are of almost equal importance with the educational features. A community spirit is developed. Interest in the greatest institution of any district, the school, is fostered. Civic pride and community betterment are encouraged. Destructive criticism is unpopular. Constructive criticism enables a community to obliterate the mistakes of the past and to create that which endures. Sectarianism in religion finds no chance for expression in a well administered home and school league. There is no place for political discussions. The home and school association meetings should not be used as an occasion on which to develop selfish interests of any kind whatever. There is no organization in a district that is more democratic than a home and school league. There is no place for caste. Parents have a common interest, the education of their children. They are searching for the best methods and what is best for one child is likewise best, generally, for others. The social hour, with light refreshments after the program of the evening, offers an opportunity for the people of a community to become acquainted with each other. Discussions among men and women of the community develop powers of leadership not generally known to exist. Let me emphasize the importance of wise direction and administration of a home and school league to bring about these results. 


\section{The Professional Work of the Schools}

The home and school league should not attempt to do the professional work of the teachers or superintendent of the school. It should not assume nor usurp the authority and function of the school board which is elected to perform certain administrative functions and which is responsible for the financial affairs of the school district. It is, however, possible for it to participate in many educational activities which supplement the regular work of teachers and school boards and thus enrich the opportunities offered to the children and older persons of the community.

This school district, a suburban borough of approximately five thousand people, has profited greatly by the initiative, the support and the participation in school activities given by the home and school league. I venture to name some of the interests of the league of this borough which have contributed towards the development of an educational ideal and to the material equipment of the school plant.

(1) Procuring a public playground,

(2) Procuring a new school building,

(3) Decorations for the school building,

(4) A club house for the playground,

(5) Responsibility for supervision of evening work in the school building.

The home and school league cannot be credited with having been wholly responsible for the success of the interests just named. In many instances it started the movement and helped with it until its consummation. In other cases it helped with the movement after the starting of it by an individual or another community interest.

\section{Procuring a Public Playground}

A committee of the league was appointed to look into the matter of procuring available land for a public recreation field. Most of the apparently desirable land had been preempted and partly built upon. A tract of three and one-half acres, well located but ungraded and with wild growths upon it was recommended. The purchase price was approximately six thousand dollars. The home and school league was young and not especially influential at the time. It recommended the formation of a Playground Association, an organization in itself, to work out a plan for securing 
possession of the land. Popular subscriptions were solicited amounting to four thousand dollars; the school board was asked to accept the four thousand dollars, to pay the balance on the land, and to assume the administration and supervision of it. Knowing that it had the support of the Home and School League representing a majority of the parents and taxpayers, the school board proceeded with the undertaking. Now one of the assets of the borough is a well-graded recreation field with football and baseball fields, tennis courts, swings, etc. A club house has been procured and recently all of the non-sectarian organizations of the district joined in a successful effort in the form of a country fair, raising eleven hundred dollars towards equipping the club house with shower baths, lockers, toilets, rest rooms, etc. The community interest in the effort to procure and equip a club house was remarkable inasmuch as all organizations including the home and school league joined unselfishly in a community project. The success of the effort of the people led an influential citizen to add to the playground ten more building lots at an expense of approximately five thousand dollars.

\section{Procuring a New School Building}

Membership in the home and school league increased from an original thirty-five to over six hundred in five years. The auditorium of the old school building would not accommodate the growing organization. The extension of school interests encouraged by the home and school league was prevented on account of lack of space and facilities. A school loan was proposed. This meant increased taxes for maintenance and liquidation of debt. The school board requested that the home and school league discuss the problem and furnish a means whereby the citizens might give expression to their feelings relative to the matter. Inasmuch as the borough council had just authorized a loan of seventy-five thousand dollars for street improvement there was considerable doubt about the success of another loan, of sixty thousand dollars for school uses. Discussion of the subject left no doubt in the minds of the school authorities of the interest in the school loan. The voters authorized the loan and in fourteen months a new high school building, with auditorium seating one thousand, a gymnasium ninety by forty-five by fifteen feet and sufficient class rooms was ready for school and community uses. By means of sliding doors and movable partitions 
the auditorium can be divided into six large class rooms. Movable and revolving chairs permit of adjustments to suit various uses for which the large room is adapted.

\section{Schoolroom Decoration}

The home and school league took up the matter of schoolroom decoration. A Shakespeare evening was proposed. Local talent, together with some outside assistance, was available to give readings and interpretations of Shakespearian dramas. Members of the league sold the tickets and attended in large numbers. Over two hundred dollars were thereby contributed to the school decoration fund. The league also joined with the school children in paying off the first hundred dollars of indebtedness upon the club house.

\section{Supervision of Evening Classes}

The home and school league offered its services to the school board in conducting evening interests in the new school building. After the board had a complete outline of the plans of the league it accepted the offer of the league, allowing it to proceed with the execution of its plans for the use of the school building. Three committees were appointed, one for evening classes, one for social functions, and one for gymnasium activities. Classes were organized for the study of stenography, typewriting and Spanish. A gymnasium class for women was established. Each member of these classes was expected to share the expense of the tuition and janitor service only, the school board being responsible for light, heat and other resources of the school plant. In addition to the classes named, a class for boys was organized for Friday evenings. The school board paid the instructor and janitor and the home and school league supervised the class. The numerous social functions of the people of the district made it inadvisable for the committee on social affairs to arrange for many social functions although it was willing and ready to do all that it had planned.

\section{INFLUENCE LOCALLY}

There is no standard by which the influence of the home and school league itself can be measured. One can infer from the foregoing statements that the influence is great and good. In addition to that which has been described the influence upon the actual 
administration, discipline and attitude towards the school has been marked. Teachers frequently refer to conferences they have had with parents at the home and school meetings. Pupils understand that parents and teachers generally are in accord in matters of study, discipline, home study, health, care of property and respect for authority. A spirit of coöperation has been developed. Teachers realize that the parents' point of view is to be considered and respected. Home conditions of study and work are better understood. In like manner the parent is made to realize that the teacher has rights and privileges, that she is a professional person worthy of respect, with authority, and with unselfish motives generally. In some cases in which teachers have failed to measure up to reasonable expectations of parents, when a dictatorial, unprofessional and unsympathetic attitude has been assumed, the teacher is made to realize that a different attitude must be shown and that none but teachers who are willing to act in loco parentis will be retained in the teaching corps.

The influence of the home and school league upon the community in general is quite as marked as that upon the school in particular. As indicated above, it has been influential in developing a community spirit; it has added to the material resources of the community; it has aided greatly in removing the schools from political domination; it has furnished a forum for the discussion of problems for the educational and moral betterment of the people; it has fostered and actually performed functions not the duty of any legally constituted authorities to perform; it has unselfishly gone about its work of doing good for children and their parents.

It is well known that school boards, town councils and other legally constituted governing bodies can perform their duties best where they are supported by those governed. The home and school league, when in the right relations with the school board is an interpreter of community ideas relative to school matters. It can be made an instrument of tremendous advantage to a school board that really desires to give the people what they want educationally. It shows the greatest lack of wisdom on the part of either organization to antagonize the other. The writer being secretary of the board of school directors and an officer in the home and school association is in a position to judge of the relations existing between the two bodies of this district. The perfect harmony existing, the 
mutual support given, and the respect each body has for the opinions of the other, are factors contributing greatly towards the normal school conditions of the district.

\section{WIDER INFLUENCES}

The influence of a home and school association is not necessarily confined to the home district. Associations have joined for mutual help and coöperation. They are instrumental in the formation of associations in other school districts. They have the missionary spirit of helpfulness and uplift. Delaware County, Pennsylvania, early had a league of home and school associations. Two meetings a year are held at different places in the county. Representatives of the various local associations go to the county meetings and give and receive ideas for betterment. The county league of associations has a committee whose duty it is to go to places where there are no associations and encourage the formation of them. The spheres of influence extend into other counties and other states. No educational movement of recent years has done more towards educating the parents and teachers to the needs of the community than the home and school associations. Their spirit is coöperation, not dictation. Their criticism is constructive, not destructive. Their aim is the betterment of school conditions. They have in mind the welfare of the children and their parents. They are building on broad foundations and are building for the future. 